\title{
VISUOMENĖS VAISTINĖSE TEIKIAMŲ PASLAUGU PRIEINAMUMO JUDĖJIMO NEGALIĄ TURINTIEMS ŽEMAITIJOS REGIONO GYVENTOJAMS TYRIMAS
}

\author{
Regina Motienė, Greta Kutkaitytė \\ Kauno kolegijos Medicinos fakulteto Farmakotechnikos katedra
}

Raktažodžiai: visuomenès vaistinè, farmacijos specialistas, judejjimo negalia, farmacinès paslaugos prieinamumas.

\begin{abstract}
Santrauka
Judejjimo negalią turinčių gyventojų skaičius Lietuvoje kiekvienais metais didejja. Neiggalieji turi teisę savarankiškai ir nepriklausomai naudotis visuomenès teikiamomis paslaugomis. Viena iš svarbiausių yra farmacinè paslauga, teikiama visuomenès vaistinèse. Dèl neigaliesiems nepritaikytos aplinkos šias paslaugas gauti dažniausiai yra sudètinga, todèl labai aktualu ịvertinti visuomenès vaistinėse teikiamų paslaugų prieinamumą judejjimo negalią turintiems gyventojams.

Rezultatai. Tyrimo metu nustatyta, kad tik trečdalis visuomenès vaistinių Žemaitijos regione pritaikytos neigaliesiems. Mažiau nei pusè (40,9 proc.) aplankytų vaistinių yra riboto prieinamumo (galima asistento pagalba), o likusi dalis visiškai neprieinama. Geriausias visuomenès vaistinių oficinos prieinamumas neigaliesiems yra prekybos centrų vaistinėse.
\end{abstract}

\section{Ivadas}

Siandieninèje visuomenejje pagalba neiggaliajam dažniausiai siejama su jo integracija, ugdant visuomenę priimti žmonių kitoniškumą kaip normalų reiškinị ir siekti padèti tapti visaverčiu visuomenès nariu [1]. Pagrindinès neigaliujų patiriamų sunkumų priežastys - visuomenès negebejjimas tinkamai suteikti paslaugas ir adekvačiai tenkinti neigaliujų poreikius [2]. Mokslinèje literatūroje kai kurie neigalieji buvo apibūdinti kaip nematomi farmacijos specialistams, nes vaistininkai neturi pakankamai žinių ar patirties, sprendžiant šias problemas [3]. Nesutvarkyti takeliai, specialaus panduso ar lifto nebuvimas ịstaigoje, ịvairūs laiptai - visa tai yra didelè kliūtis neiggaliam žmogui, kuris siekia būti visuomenès dalis ir gyventi visaverti gyvenimą [4].Vienas iš svarbiausių daugelio sričiu specialistų rūpesčių - igyvendinti paslaugos bei informacijos prieinamumo visiems piliečiams strategijas [5].

Norint užtikrinti farmacinių paslaugų prieinamumą kiekvienam gyventojui, Lietuvos Respublikos farmacijos istatyme ir ji papildančiuose teisès aktuose nustatyta, jog juridinis asmuo, norédamas gauti vaistinès veiklos licenciją, privalo turèti tinkamas patalpas ir ịrengimus, o ịstaigos aplinka turi būti pritaikyta neigaliesiems [6,7].Vaistinių oficinos prieinamumas judejjimo negalią turintiems žmonèms Lietuvoje nèra pakankamai ištirtas. Atliktas vienas tyrimas Kauno regione, kurio metu nustatyta, jog 13 procentu visuomenès vaistinių nepritaikytos judejimo negalią turintiems žmonèms, 34 procentai - iš dalies pritaikytos ir 53 procentai vaistinių [8] visiškai pritaikytos. Kokia situacija kituose Lietuvos regionuose, skelbtų mokslinių darbų nepavyko aptikti.

Tyrimo tikslas - nustatyti visuomenés vaistinèse teikiamų paslaugų prieinamumą judejjimo negalią turintiems Žemaitijos regiono gyventojams.

\section{Tyrimo objektas ir metodai}

Visuomenès vaistinėse teikiamų paslaugų prieinamumas. Kokybinis tyrimas, atvejo analize, slapto paciento eksperimentas. Kokybiniam tyrimui pasirinktos 22 visuomenès vaistinès Žemaitijos regione: 7 Kretingoje, 7 Klaipèdoje ir 8 Palangoje.

\section{Tyrimo rezultatai ir aptarimas}

Vertinant visuomenès vaistinių prieinamumą neigaliesiems, buvo vertinama išorine ir vidiné vaistinių aplinka, stebima farmacijos specialisto reakcija ị pacientą, judanti neigaliojo vežimèlyje. Tyrimo metu duomenys ir reikalinga informacija buvo registruojama išvažiavus iš vaistinès, pildant iš anksto parengtą visuomenès vaistinių vertinimo anketą, užsirašant faktus, kurie gali būti reikalingi atliekant kuo išsamesnę vertinimo analizę.

Tyrimas atliktas naudojant iš anksto parengtą visuomenès vaistinių vertinimo anketą, kurią sudaro 26 vertinimo kriterijai, atitinkantys statybos techninio reglamento nuostatas [9].

Išorinei aplinkai vertinti buvo taikomi automobilių aikštelès pritaikymo neigaliesiems kriterijai: kliūtys prie ịejimo, grindinio kokybé, patekimas ị objektą, durų pritaikymas ir kt. Vidaus aplinkai nustatyti buvo vertinama galimybė judèti vaistinès viduje, savitarnos skyriaus buvimas, farmacijos 
specialisto veiksmai ir kt.

Tyrimo duomenų analizei naudoti aprašomosios statistikos metodai. Gauti duomenys apdoroti ir grafinè analizè atlikta naudojant Microsoft Excel programą. Tyrimo duome-

1 lentelè. Visuomenès vaistinių prieinamumo tipai miestuose.

\begin{tabular}{|l|c|c|c|}
\hline \multirow{2}{*}{ Miestas } & \multicolumn{3}{|c|}{$\begin{array}{c}\text { Vaistinès prieinamumo } \\
\text { neigaliesiems tipas }\end{array}$} \\
\cline { 2 - 4 } & $\begin{array}{c}\text { priei- } \\
\text { nama }\end{array}$ & $\begin{array}{c}\text { riboto } \\
\text { prieina- } \\
\text { mumo }\end{array}$ & $\begin{array}{c}\text { nepriei- } \\
\text { nama }\end{array}$ \\
\hline Klaipèda & 3 & 2 & 2 \\
\hline Kretinga & 2 & 4 & 1 \\
\hline Palanga & 3 & 3 & 2 \\
\hline Iš viso: & 8 & 9 & 5 \\
$(36,4 \%)$ & $(40,9 \%)$ & $(22,7 \%)$ \\
\hline
\end{tabular}

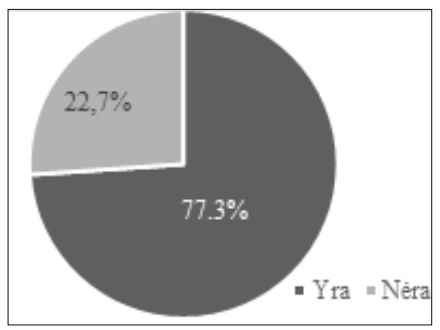

1 pav. Automobilių aikštelių prie vaistinių dažnis.

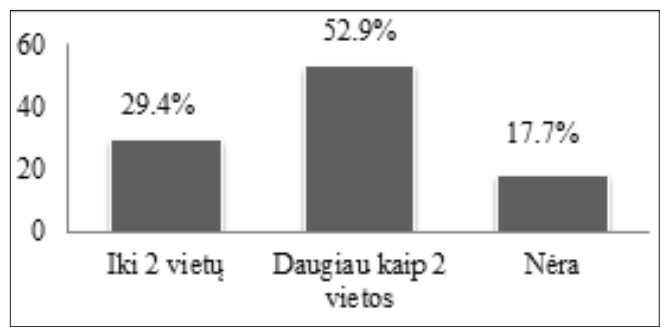

2 pav. Automobilių parkavimo vietų skaičius neịgaliesiems.

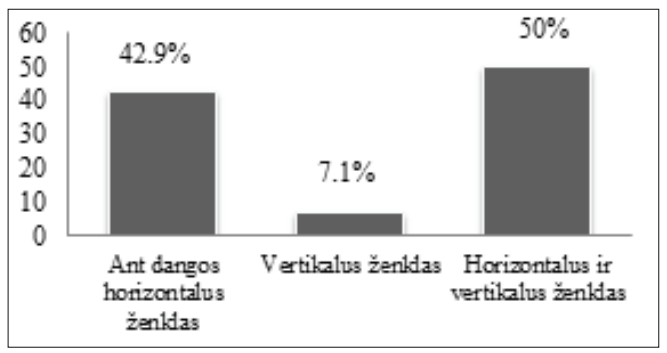

3 pav. Automobilių parkavimo vietų žymėjimas. nys pateikiami ir analizuojami procentine išraiška.

Atliekant eksperimentą, kurio metu buvo siekiama ịvertinti patekimo i visuomenès vaistines galimybes žmonėms neigaliojo vežimèlyje, nustatyti trys visuomenės vaistinių prieinamumo tipai: prieinama, riboto prieinamumo ir neprieinama (1 lentelè).

Atsižvelgiant ị surinktus duomenis paaiškejjo, kad net 22,7 proc. aplankytų visuomenès vaistinių yra neprieinamos judejjimo negalią turintiems žmonèms. Didžiausią aplankytų vaistinių dali (40,9 proc.) sudaro riboto prieinamumo vaistinès, t.y. žmogus, judantis neiggaliojo vežimèlyje, ị vaistinę gali patekti tik padedamas asistento. 36,4 proc. vaistinių neigaliesiems prieinamos savarankiškai.

Norint nustatyti visuomenès vaistiniu prieinamumą, pirmiausia buvo vertinama išorinè aplinka. 22,7 proc. Žemaitijos regione aplankytų visuomenès vaistinių šalia neturi automobilių aikštelès. Tai didelè problema, nes palikus automobilį toliau nuo vaistinès, kelias neigaliojo vežimèliu pailgèja,

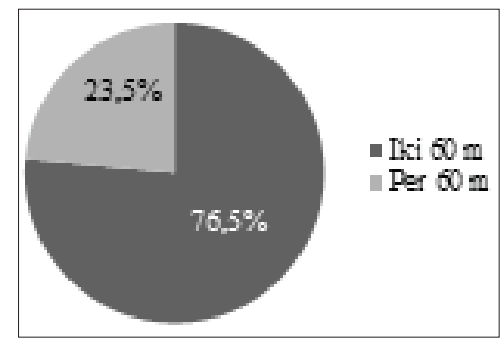

4 pav. Atstumas nuo automobilių aikštelès iki įejjimo.

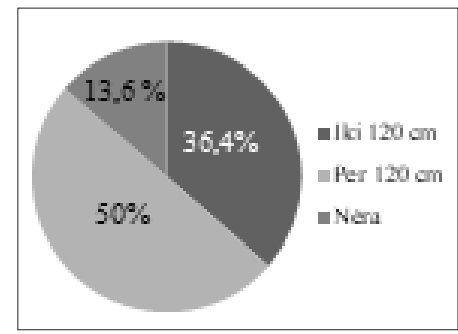

5 pav. Panduso įrengimas.

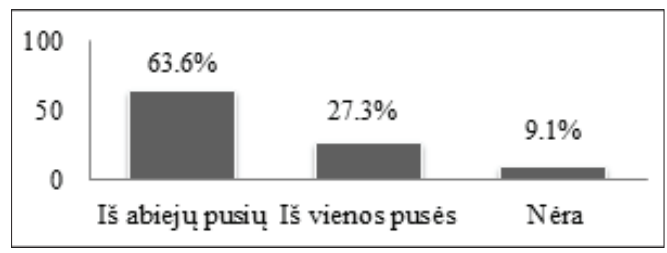

6 pav. Turèklų ịrengimas prie panduso.

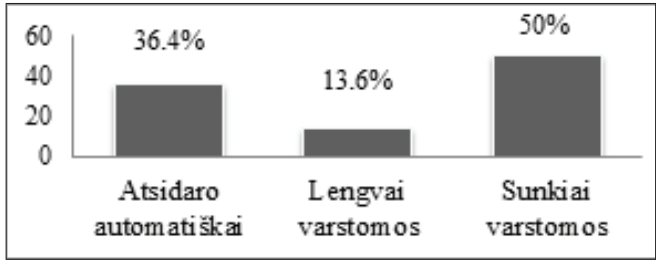

7 pav. Durų atidarymo būdai.

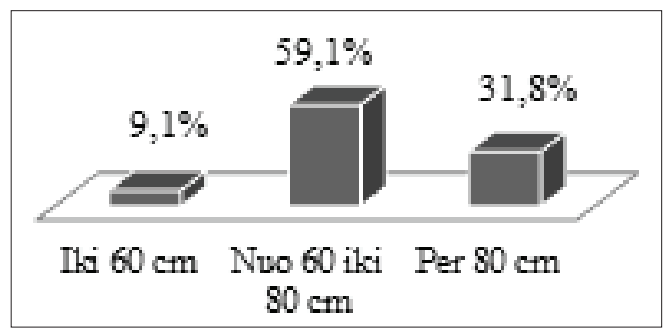

8 pav. Durų parametrai. 
darosi sudètinga ịveikti reikiamą atstumą. Didžioji dalis (77,3 proc.) vaistinių turi automobilių aikšteles, tačiau iš jų net 17,7 proc. nèra vietų, pritaikytų neigaliesiems (1 pav.).

Daugiau nei pusèje aikštelių $(52,9$ proc.) irengtos daugiau kaip 2 vietos, o likusioje dalyje $(29,4$ proc.) - iki 2 vietu (2 pav.).

50 proc. aikštelių, pritaikytų neigaliujų automobiliams, paženklintos horizontaliai ir vertikaliai. 42,9 proc. paženklinta ant dangos ir tik 7,1 proc. aikštelių paženklinta vertikaliai. Automobilio stovejjimo vietos, pažymètos neigaliujų ženklu, dažniausiai ịrengiamos arčiausiai prie pagrindinio iejejimo i pastatą, jos platesnès, todèl asmuo, turintis judejjimo

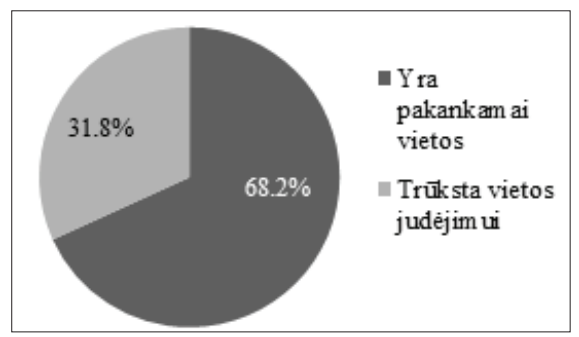

9 pav. Judèjimo galimybè vaistinèje.

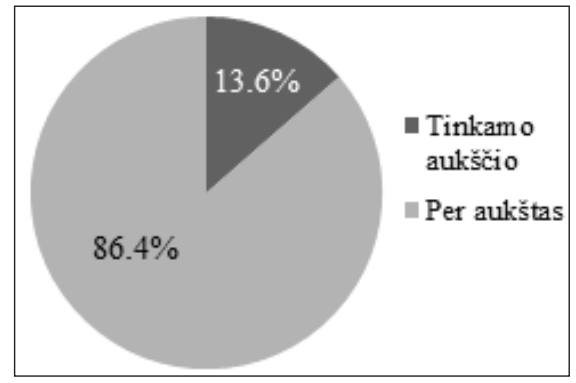

10 pav. Prekystalio aukštis.

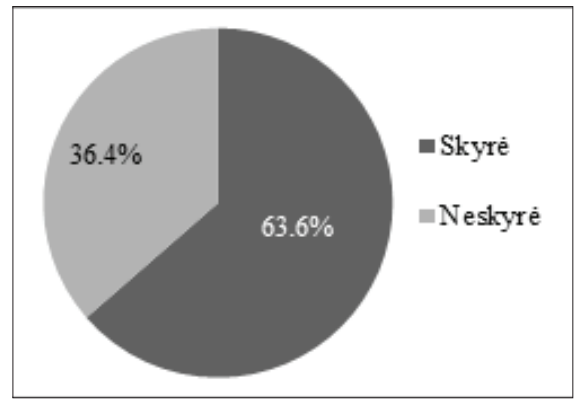

11 pav. Farmacijos specialisto dèmesio dažnis. negalią, gali nevaržomai judèti ir greitai pasiekti reikiamą vietą (3 pav.).

Vadovaujantis statybos techniniu reglamentu, atstumas nuo neigaliuju automobilio vietos iki pagrindinio ịejjimo ị pastatą turètų būti ne didesnis kaip 60 m. (4 pav.)

Atliekant tyrimą pastebèta, kad ne visų aikštelių atstumas yra tinkamas. 76,5 proc. tyrime stebètų aikštelių atitiko reikalavimus, o 23,5 proc. atstumas buvo didesnis nei 60 metrų.

Net pusejje aplankytų vaistinių neįrengti pandusai. 36,4 proc. vaistinių pandusai buvo iki $120 \mathrm{~cm}$ pločio, o 13,6 proc. vaistinių - platesni nei $120 \mathrm{~cm}$. Nustatyta, kad didelè dalis pandusų neatitinka reikalavimų ir yra nepritaikyti važiuoti neiggaliojo vežimèliu (5 pav.). Iš visų įrengtų pandusų 63,6 proc. neigaliujų gali užvažiuoti tik padedami asistento, 27,3 proc. pandusai per statūs, dèl to neįmanoma užvažiuoti net padedant asistentui. 9,1 proc. atitinka visus reikalavimus ir yra tinkamai pritaikyti savarankiškai judèti neigaliojo vežimèlyje (6 pav.).

63,6 proc. pandusų turèklai ịrengti abiejose pusėse, 27,3 proc. vienoje pusejje ir 9,1 proc. turéklų nebuvo.

50 proc. Zemaitijos regiono miestuose aplankytų vaistinių neturi slenksčio tarpduryje, todèl nèra problemos patekti ị vidų. 27,3 proc. vaistinių slenkstis tarpduryje yra iki $2 \mathrm{~cm}$, o 22,7 proc. vaistinių slenkstis aukštesnis nei $2 \mathrm{~cm}$ [9]. Kuo aukštesnis slenkstis tarpduryje, tuo didesnè tikimybè, kad žmogus neiggaliojo vežimèlyje negalès savarankiškai įvažiuoti ị vaistinę, todèl reikalinga asistento pagalba.

Nustatyta, kad net 50 proc. visuomenès vaistiniu sunkiai varstomos durys ( 7 pav.), todèl neigaliesiems reikalinga asistento pagalba patekti ị vidų. Nedidele dalis durų (13,6 proc.) lengvai varstomos ir tik 36,4 proc. atsidaro automatiškai (7 pav.).

Vienas iš vertinimo kriterijų buvo durų varčių nekliudomas plotas. Pagal statybos techninị reglamentą, prie pagrindinio ịejimo turi būti ịrengta lygi aikštelè, ne mažesnè kaip 150 iš $150 \mathrm{~cm}$ [9]. Gautieji duomenys parodè, kad pusès aplankytų objektų plotas prie pagrindinio ịejimo buvo mažesnis nei 150 iš $150 \mathrm{~cm}$, o kitos tokios pat dalies - didesnis. Durų varčių nekliudomas plotas ypač svarbus tais atvejais, kai durys varstomos, nes neigaliajam reikia daugiau vietos laisvai atsidaryti duris ir ịvažiuoti ị pastatą ( 8 pav.).

Vertinant duris, buvo kreipiamas dèmesys i jų plotị, nes tai gali tapti viena iš kliūčių, dèl kurios judejjimo negalią turintis žmogus negali patekti į vaistinę. Atsižvelgiant ị statybos techninị reglamentą, neiggaliesiems pritaikytų durų plotis turi būti per $80 \mathrm{~cm}$ [9]. 8 paveiksle galima matyti, kad daugiau nei pusés vaistinių durų plotis yra tarp $60-80 \mathrm{~cm} .9,1$ proc. durų plotis yra iki $60 \mathrm{~cm}$, todẻl ị šias vaistines patekti su neịgaliojo vežimèliu nepavyko.

Siekiant išsiaiškinti visuomenès vaistinėse teikiamų paslaugų prieinamumą, buvo vertinama vidinè aplinka.

Tyrimo metu nustatyta, kad tik vienoje iš aplankytų vaistinių buvo ịrengtas iškvietimo mygtukas. Sis elementas turi didelị privalumą negalią turintiems žmonèms, nes taip galima lengviau ir greičiau išsikviesti farmacijos specialistą, kuris padètų patenkti į vaistinę ar suteiktų farmacinę paslaugą, nevažiuojant ì vidų.

Daugiau nei pusejje vaistinių (68,2 proc.) yra pakankamai vietos judèti su neigaliojo vežimèliu. Likusioje dalyje vaistinių judèjimas ribotas. Sunku važiuoti vežimėliu tarp stelažų, mažai vietos apsisukti. Tyrimo metu pastebèta, kad beveik visose vaistinèse, kuriose pakanka vietos judèti, yra didelis savitarnos skyrius ( 9 pav.).

Daugumoje tirtų visuomenès vaistinių (86,4 proc.) nęrengti tinkamo aukščio prekystaliai, reikalingi patogiai aptarnauti neigaliuosius. 13,6 proc. 
vaistinių ịrengti tinkamo aukščio prekystaliai, tačiau tyrimo metu pastebèta, kad tinkamo aukščio kasose neaptarnaujama. Toks farmacijos specialisto elgesys gali formuoti neigiamą specialistų ir vaistinès ịvaizdị. Aukštas prekystalis dažniausiai apsunkina paciento ir farmacijos specialisto bendravimą bei atsiskaitymą (10 pav.).

Atliekant slapto paciento tyrimą, buvo stebima farmacijos specialistų reakcija ị judejjimo negalią turintị asmenį. Trečdalyje aplankytų visuomenès vaistinių farmacijos specialistas neskyrè specialaus dèmesio (neprièjo, nepasiteiravo, ar reikia pagalbos), neaptarnavo prie žemesnès kasos, nors tokia buvo ịrengta. Pastebèta, kad nors specialaus demesio neskyré, aptarnavo maloniai ir suteikè visą reikalingą informaciją.

Daugiau nei pusėje aplankytų vaistinių farmacijos specialistai atkreipé dėmesị i asmeni, judantị neįgaliojo vežimėlyje, teiravosi, ar reikalinga pagalba judèti vaistinejje. Savitarnos skyriuje suteike naudingos informacijos renkantis preparatus, pateikè nemažai pasiūlymų, renkantis maisto papildus. Buvo suteikta visa reikalinga informacija apie vaistinių preparatų vartojimą, veikimą. Pasiteiravus apie kraujospūdžio matavimo paslaugą, farmacijos specialistas maloniai pasisiūlè padèti ir pamatavo kraujospūdị. Pasitaikè atvejis, kai farmacijos specialistas, aptarnaudamas prie kasos, stovejjo šalia prekystalio, o ne už jo, kad būtų patogiau bendrauti. Toks farmacijos specialisto elgesys motyvuoja sugrižti ị tą pačią vaistinę kitą kartą (11 pav.).

\section{Išvados}

1. Nustatyti trys visuomenès vaistinių prieinamumo judejjimo negalią turintiems gyventojams tipai: prieinama, riboto prieinamumo (padedami asistento) ir neprieinama. Didžiausia vaistinių neprieinamumo problema yra pandusų nebuvimas arba netinkamas jų ịrengimas. Tik vienoje iš visų aplankytų vaistinių buvo įrengtas iškvietimo mygtukas. Didelèje dalyje visuomenès vaistinių nèra tinkamo aukščio prekystalių, reikalingų patogiai aptarnauti neiggaliuosius. Pusėje visuomenès vaistinių sunkiai varstomos durys, todèl patekti i vaistinés vidų reikalinga asistento pagalba.

2. Atlikta atvejo analizè parode, kad net trečdalyje aplankytų visuomenès vaistinių farmacijos specialistas neigaliajam neskyrè specialaus dèmesio (neprièjo, nepasiteiravo ar reikia pagalbos), tačiau maloniai aptarnavo ir suteikè visą reikalingą informaciją. Didžioji dalis farmacijos specialistų skyrė pakankamai dėmesio, konsultavo apie vaistinius preparatus, maisto papildus ir jų vartojimą, teiravosi, ar reikalinga pagalba judèti savitarnos skyriuje.

\section{Literatūra}

1. Bartkutè I., Čižikienė J. Asmenų su fizine judejjimo negalia socialinè integracija Lietuvoje: padèties analizè. Sveikatos mokslai, 2013; 23(1):91-5.

https://doi.org/10.5200/sm-hs.2013.016

2. Guščinskienė J., Čiburienė J. Lietuvos neigaliujų įtrauktis it aukštaji mokslą ir darbo rinką: socialinès atsakomybès aspektas.
Ekonomika ir vadyba, 2011(16):501-9.

3. Flood B, Henman MC. Case study: hidden complexity of medicines use: information provided by a person with intellectual disability and diabetes to a pharmacist. British Journal of Learning Disabilities 2015;43(3):234-42.

https://doi.org/10.1111/bld.12121

4. Steenstra IA, Anema JR, Van Tulder MW, Bongers PM, De Vet HC, Van Mechelen W. Economic evaluation of a multistage return to work program for workers on sick-leave due to low back pain. Journal of Occupational Rehabilitation. 2006;16(4):557-78.

https://doi.org/10.1007/s10926-006-9053-0

5. Rudžionienė J., Lašinytė I. Informacijos paslaugos neigaliesiems: informacinès prieigos organizavimas Danijoje. Informacijos mokslai, 2011;1(57):39-54.

https://doi.org/10.15388/Im.2011.0.31356.

6. "Dèl reikalavimų vaistinėms patvirtinimo": Lietuvos Respublikos sveikatos apsaugos ministro $2003 \mathrm{~m}$. sausio $7 \mathrm{~d}$. ịsakymas Nr. V-7.

7. X-709. Lietuvos Respublikos farmacijos įstatymas.

8. Andrulis M. Vaistinių prieinamumas fizinę negalią turintiems asmenims, 2017.

9. "Dèl STR 2.03.01:2001 "Statiniai ir teritorijos. Reikalavimai žmonių su negalia reikmėms" patvirtinimo": Lietuvos Respublikos aplinkos ministro $2001 \mathrm{~m}$. birželio 14 d. įsakymas Nr. 317.

\section{ACCESSIBILITY OF SERVICES PROVIDED BY PUBLIC PHARMACIES FOR RESIDENTS WITH MOBILITY DISABILITIES OF THE ŽEMAITIJA REGION}

\section{R. Motienè, G. Kutkaitytė}

Keywords:public pharmacy, pharmacy specialist, movement disability, pharmaceutical care.

Summary

Lithuania has a large number of people with mobility disabilities and that number is increasing every year. Even the individuals with disabilities has the right to use public services independently. One of the most important service is the pharmaceutical service provided by public pharmacies. However, due to misapplication of the surroundings it's difficult to receive these kind of services. This is why it is really important to assess the accessibility of services provided by public pharmacies to people with reduced mobility. During the experimental study, it became clear that only one third of the public pharmacies in the Žemaitija region are adapted for the population with mobility disabilities. Less than half $(40.9 \%)$ of pharmacies that have been visited have limited availability (the help of an assistant) and the rest is completely unavailable. According to the data recorded in the study, the best availability of public pharmacies for disabled people is in pharmacies in supermarkets.

Correspondence to: regina.motiene@go.kauko.lt

Gauta 2019-10-11 